S. Louis, 40, 901 (1952). - 12. Troeld, L. und B. Aberg, Scand. J. Clin. Laborat. Invest., 4, 4 (1952). - 13. Engstrand, L. und B. Áberg, Lancet, London, 258, 1071 (1950). - 14. Davies und Ricketrs, Brit. J. Pharmacol., 21, 221 (1963). - 15. BLoom, W. L. und M. L. Wrulcox, Proc. Soc. exp. Biol. Med., 76, 3 (1951). 16. RedeI, A. und S. NAGY, Nature, London, 191, 173 (1961). 17. WALLENIUS, G., unpubliziert. - 18. AppeL, W., unpubliziert. 19. Bourrillon, R., Compt. rend. Soc. biol., Paris, 147, 238 (1953).
- 20. Durham, W., W. Bloom, G. Lewis und E. Mander, Publ. Hith. Rep., Wash. 65, 670 (1950). - 21. Dimler, R. J., H. A. Davies, G. J. Gill und C. E. Rist, Analytic. Chem., 26, 1142 (1954). - 22. Scotr, T. A. und E. H. Mervin, Analytic Chem., 25, 1656 (1953). - 23. Grönwall, A. und K. Wikström, Acta Soc. med. Upsal., 59, 24 (1953). - 24. Schurz, G. V., Makromolekulare Chem., 5, 83 (1950).
Dr. W. Appel 6700 Ludwigshafen/Rh. 2 Knoll AG, Postfach

\title{
The non-destructive detection of amino acids on thin-layer chromatograms using I-Fluor-2,4-Dinitrobenzene ${ }^{1}$ )
}

\author{
By G. Pataki, J. Borko and A. Kunz \\ From the Analytical Department, Laboratory for Cbromatography, Robapharm Ltd. Basle, Switzerland
}

(Eingegangen am 4. Juni 1968)

An improved method for the non-destructive detection of amino acids separated on thin-layer chromatograms is described. The reaction of amino acids with 1-Fluor-2,4-Dinitrobenzene in situ allows the detection of $10 \mathrm{nMoles}$ on two-dimensional and 0.5 to. $1 \mathrm{nMoles}$ on onedimensional chromatograms. The technique makes possible reaction cbromatograpby and multidimensional cbromatography of amino acids, i. e. the more unambiguous identification in complex mixtures.

Eine verbesserte Methode zum zerstörungsfreien Nachweis von Aminosäuren auf Dünnschicht-Chromatogrammen wird beschrieben. Die Umsetzung von Aminosäuren mit 1-Fluor-2,4-Dinitrobenzol in situ erlaubt den Nachweis von 10 nMolen in zweidimensionalen und 0,5 bis $1 \mathrm{nMolen}$ in eindimensionalen Chromatogrammen. Die Technik ermöglicht die Reaktionschromatographie und die multidimensionale Cbromatographie von Aminosäuren, d. h., eine eindeutige Identifizierung in komplexen Gemischen.

The non-destructive detection of amino acids on thinlayer chromatograms, using 2,4-Dinitrofluorbenzene (DNFB), was reported in a preliminary communication (2). The technique described in this paper (2) has been subsequently used, in an improved version, to detection and reaction chromatography of amino acids $(3,4)$. In the present paper the improved procedure will be described.

\section{Material and Methods}

Material

MN-300-cellulose (Macherey, Nagel + Co. Düren)

Kieselgel G (Merck, Art. 7731)

Plastic foils for TLC, DC GA 1190 (Galenopharm, Geneva)

Toronto starch (Bender + Hobein, Zurich)

1-Fluor-2,4-Dinitrobenzene puriss (DNFB) (Fluka, Buchs, Switzerland)

Ninhydrin (Hoffmann La Roche, Basle)

Sodium carbonate (Merck, Art. 6391)

Sodium hydrogen carbonate (Merck, Art. 6329)

n-Butanol (Merck, Art. 9628)

Isopropanol (Merck, Art. 9634)

Formic Acid (Merck, Art. 264)

tert-Butylalcohol (Merck, Art. 9629)

Ethylmethylketone (Merck, Art. 9708)

Glacial Acetic Acid (Merck, 90063)

25\% Ammonia (Merck, Art. 5432)

$\beta$-Naphthoquinone-4-sulfonic acid-sodium (Merck, Art. 6531)

1) 9th communication on "Application of thin-layer chromatography in sequence analysis of peptides". 8th communication cf. Reference (1).
DNP-amino acids (Serva, Entwicklungslabor, Heidelberg and Mann Research Laboratories, New York)

Amino Acid Standard solutions set No. 1, Catalogue No. 2058 (Shandon, London)

Methylalcohol (Merck, Art: 6009)

Sodium hydroxide (Merck, Art. 6496)

Chloroform (Merck, Art. 2445)

\section{Reagents}

DNFB-solution: $1 \%(\mathrm{w} / \mathrm{v})$ in absolute methyl alcohol (the solution must be freshly prepared!) (5)

1M Bicarbonate-buffer $\mathrm{pH}$ 8.8: $8.4 \mathrm{~g} \mathrm{NaHCO}_{3}$ dissolve (without heating!) in distilled water, $\mathrm{pH}$ adjusted to 8.8 with $2 \mathrm{~N} \mathrm{NaOH}$, and made up to $100 \mathrm{~m} /$ with distilled water (5)

Ninhydrin-solution: $0.3 \mathrm{~g}$ Ninhydrin $+100 \mathrm{~m} l \mathrm{n}$-Butanol $+3 \mathrm{ml}$ glacial acetic acid (5)

FolIN's Reagent: $0.2 \mathrm{~g} \beta$-Naphtoquinone-n-sulfonic acid-sodium + $100 \mathrm{~m} / 5 \% \mathrm{Na}_{2} \mathrm{CO}_{3}$-solution (5)

Preparation of the layers

Glass plates as well as plastic foils are coated with purified MN-300cellulose $(6,7)$, and with silica gel G-Starch (5).

Chromatography

Two-dimensional development on cellulose was carried out according to JoNES and Heathcote (8). First dimension: isopropanol/formic acid/water $(80: 4: 20 \mathrm{v} / \mathrm{v})$, and after drying with a stream of cold air (1 hour), tert- butylalcohol/ethylmethylketone $25 \%$ ammonia/ water $(5: 3: 1: 1 \mathrm{v} / \mathrm{v})$ in the second dimension. All runs were without chamber saturation.

One dimensional chromatography on silica gel was performed with chloroform/methanol $/ 25 \%$ ammonia $(2: 2: 1 \mathrm{v} / \mathrm{v})(5)$ All runs were with chamber saturation.

Detection with DNFB

When the chromatography is complete, the layer is dried (15 min. in a stream of warm air) and cooled to room temperature. The 


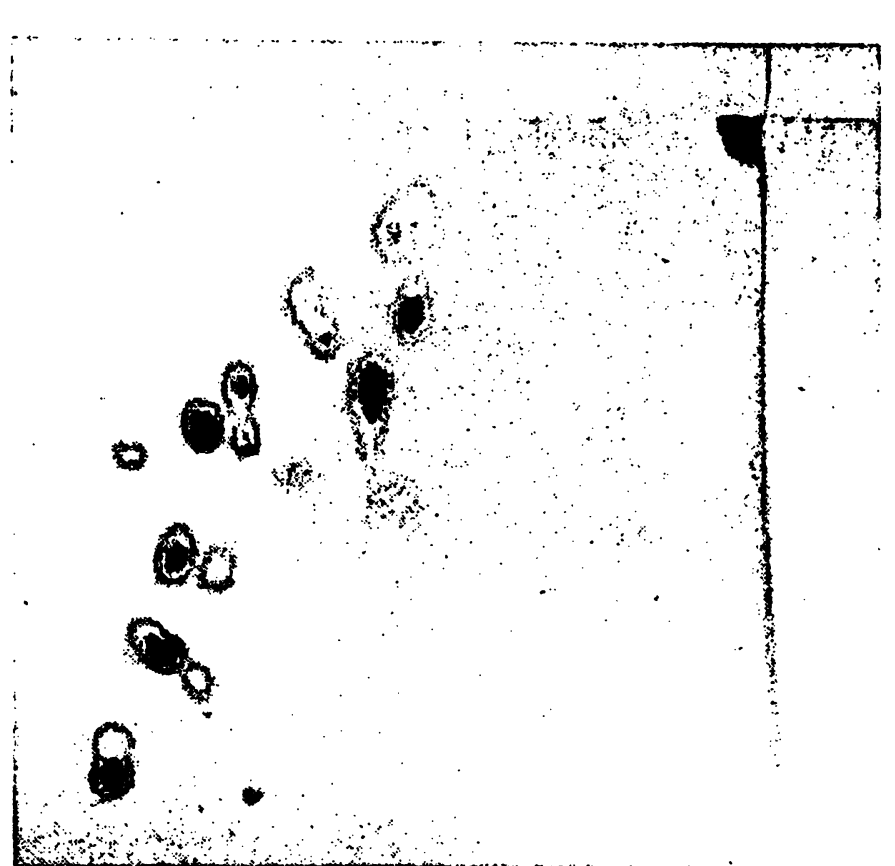

Fig. 1

Detection of amino acids with DNFB on two-dimensional chromatograms (Original UV-photograph) grams (Original UV on two-dimensional chromatoaccording to PATAKI $(6,7)$ :

Solvents: Isopropanol/formic acid/water $(80: 4: 20 \mathrm{v} / \mathrm{v})$ in the first dimension and tert-Butylalcohol/ethylmethylketone $/ 25 \%$ ammonia water $(5: 3: 1: 1 \mathrm{v} / \mathrm{v})$ in the second dimension, according to JONES and HEATHCOTE (8). 1 = Alanine, $8=$ Arginine, $10=$ Aspartic Acid $12=$ Cystine, $16=$ Glutamic Acid, $18=$ Glycine, $20=$ Histidine 22 = impurity, 23 = Isoleucine, $24=$ Leucine, $25=$ Lysine, 26 = Methionine, $32=$ Phenylalanine, $33=$ Proline, $35=$ Serine $37=$ Threonine, $38=$ Tryptophan, $39=$ Tyrosine, $40=$ Valine

chromatogram is sprayed with a $1 \%$ DNFB-solution for exactly $1 \mathrm{~min}$., and subsequently with a $1 \mathrm{M} \mathrm{NaHCO}_{3}$ buffer for exactly $20 \mathrm{sec}$. The covered plate (2) (or sheet) ist incubated in the dark at $40^{\circ} \mathrm{C}$ for $1 \mathrm{~h}$, and dried $15 \mathrm{~min}$. in a stream of warm air. Subsequently the chromatogram is laid for $15 \mathrm{~min}$. in a tank, which contains three vessels each filled with $20 \mathrm{ml}$ conc. $\mathrm{HCl}$. Of course, there is no direct contact between the layer and the $\mathrm{HCl}$-solutions. After the layers have been aired ( $3-5 \mathrm{~min}$. with a stream of cold air) the spots can be copied or photographs can be taken. After the $\mathrm{HCl}-$ procedure, 2,4-dinitrophenol is no longer visible in day-light and does not interfere with the spots.

\section{Results}

The technique described previously (2) consists of spraying with a $10 \%$ DNFB-solution followed by wash-

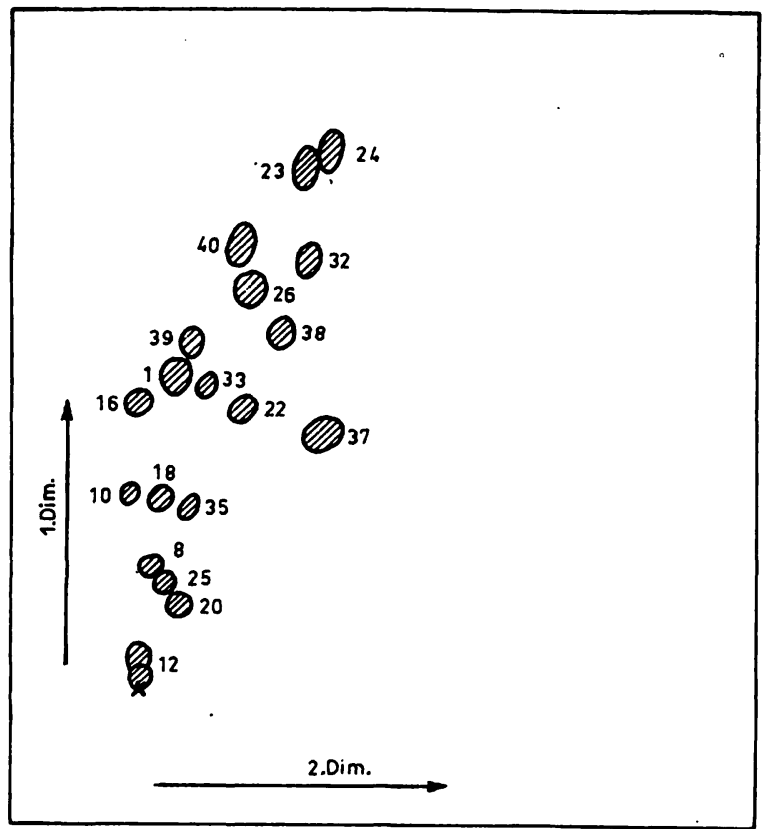

Fig. 2

Interpretation of chromatograms, according to Figure 1 . Note that the spot distribution on purified cellulose layers (plates as well as sheets) $(6,7)$ is nearly the same as reported previously $(8)$. Note that aspartic acid was not run in this particular chromatogram

ing the layer with ether. Although this procedure was capable of eliminating some of the 2,4-dinitrophenol which causes a yellow background and also interferes with the spots, the yellow colour of the layer was still a disturbing factor. Using a $1 \%$ DNFB-solution on the one hand, and replacement of the washing-procedure by a treatment with $\mathrm{HCl}$ on the other (cf. Methods), it is now possible to eliminate 2,4-dinitrophenol. Thus, the technique given in the experimental part allows the non-destructive detection of as little as about $10 \mathrm{nMole}$ of an amino acid, separated on two-dimensional chromatograms. Using one-dimensional chromatography and the detection technique described above, it is even possible to detect 0.5 to $1 \mathrm{nMoles}$ of amino acids (cf. Tab. 1).

Figure 1 shows a number of amino acids detected with DNFB on cellulose layers. Figure 2 represents the interpretation of chromatograms according to Figure 1.

Table 1

Detection limits of amino acids with DNFB on silica gel layers One-dimensional chromatography of amino acids with chloroform/methanol/25\% ammonia $(2: 2: 1 \mathrm{v} / \mathrm{v})$ (5), detection with DNFB and HCltreatment (cf. Methods)

The sensitivity is considerably lower as in the case of Ninhydrin- or Folin-reaction (cf. (4))

\begin{tabular}{|c|c|c|c|}
\hline Amino Acid & - Detection limit & Amino Acid & $\underset{\mu \mathrm{g}}{\text { Detection limit }}$ \\
\hline $\begin{array}{l}\text { Alanine } \\
\beta \text {-Alanine } \\
\alpha \text {-Amino-butyric acid } \\
\gamma \text {-Amino-butyric acid } \\
\beta \text {-Amino-iso-butyric acid } \\
\text { Arginine }-\mathrm{HCl} \\
\text { Asparagine } \cdot \mathrm{H}_{2} \mathrm{O} \\
\text { Aspartic Acid } \\
\text { Citrulline } \\
\text { Cystine } \\
\text { Cysteic Acid } \\
\text { Di-Iodo-Tyrosine } \\
\text { Ethanolamine } \\
\text { Glutamic Acid } \\
\text { Glutamine } \\
\text { Glycine } \\
\text { Histamine } \cdot 2 \mathrm{HCl} \\
\text { Histidine } \cdot 2 \mathrm{HCl} \\
\text { Homocystine } \\
\text { Hydroxyproline }\end{array}$ & $\begin{array}{l}0.05 \\
0.1 \\
0.1 \\
0.1 \\
0.05 \\
0.2 \\
0.15 \\
0.15 \\
0.2 \\
0.25 \\
0.2 \\
0.25 \\
0.1 \\
0.15 \\
0.15 \\
0.1 \\
0.1 \\
0.2 \\
0.3 \\
0.1 .5\end{array}$ & $\begin{array}{l}\text { Isoleucine } \\
\text { Leucine } \\
\text { Lysine } \cdot \mathrm{HCl} \\
\text { Methionine } \\
\text { Methioninesulfoxide } \\
\text { Methioninsulfone } \\
\text { 1-Methyl-Histidine } \\
\text { Ornithine } \cdot \mathrm{HBr} \\
\text { Phenylalanine } \\
\text { Proline } \\
\text { Sarcosine } \cdot \mathrm{HCl} \\
\text { Serine } \\
\text { Taurine } \\
\text { Threonine } \\
\text { Tryptophan } \\
\text { Tyrosine } \\
\text { Valine }\end{array}$ & $\begin{array}{l}0.15 \\
0.15 \\
0.1 \\
0.15 \\
0.1 \\
0.1 \\
0.2 \\
0.1 \\
0.2 \\
0.15 \\
0.1 \\
0.1 \\
0.1 \\
0.1 \\
0.2 \\
0.2 \\
0.15\end{array}$ \\
\hline
\end{tabular}


This chromatographic system according to JoNEs and Heathcote (8) was used, due to its high resolving power; even leucine and isoleucine are separated. The replacement of cellulose by purified cellulose (6) has only a minor influence on the separation (cf. Fig. 1 and Ref. (8)). On the other hand, the use of purified cellulose (6) has been found advantageous if rechromatograpby (i. e. chromatography in several systems: multidimensionalClbromatography) or reflectance spectroscopy of DNP-amino acids formed on the laver is to be carried out $(4,9)$. Moreover, the non-destructive detection technique described in this paper allows the reaction chromatograpby of amino acids $(3,4)$; i. e. conversion of amino acids into
DNP-derivatives at the origin followed by one or twodimensional separation of DNP-compounds formed, or one-dimensional chromatography of amino acids followed by treatment with DNFB and chromatography of DNP-derivates formed in situ in the second dimension. These techniques, which allow the more unambiquous identification of amino acids, especially from biological sources, are reported elsewhere (4). The application of non-destructive detection techniques in sequence analysis of peptides and in the analysis of amino acids in biological material (e. g. urine or blood) will be described in a subsequent paper.

\title{
References
}

1. Pataki G. and K. T. Wang, J. Chromatogr., in press. 2. Patakr, G., J. Chromatogr. 16, 541 (1964). - 3. Parakr, G., 3 rd. Symposium on Chromatography and Electrophoresis, Presses Académiques Européennes, Brussels 1966, in press. 4. Pataki, G., J. Borko, H.-Ch. Curtius and F. Tancredr, Chromatographia, in press. - 5. Patakr, G., Dünnschichtchromatographie in der Aminosäure- und Peptidchemie, W. de Gruyter
\& Co., Berlin (1966); Techniques of Thin-Layer Chromatography in Amino Acid and Peptide Chemistry, Ann Arbor Science Publ. Inc., Ann Arbor (1968). - 6. Patakr, G., J. Chromatogr. 29, 126 (1967). - 7. PATAKI, G., in Advances of Chromatography (editors: C. Giddings and R. A. Keller), Volumen 7, Dekker, New York, in press. - 8. Jones, $\mathrm{K}$. and J. G. Heathcote, J. Chromatogr. 24, 106 (1966). - 9. Pataki, G., Chromatographia, in press.

\section{Saure Glycosaminoglycane des normalen und cirrhotischen Leberbinde- gewebes vom Menschen}

\author{
Von A. Delbrück \\ Mediziniscke Hocbsciule, Zentrallaboratorium am Kranken!aus Oststadt, Hannovir
}

(Eingegangen am 10. Juni 1968)

Es wird über ein Verfahren zur Isolierung saurer Glycosaminoglycane aus Lebergewebe vom Menschen und die Auftrennung in ihre Einzelkomponenten berichtet. Dabei ergibt sich, daß etwa $90 \%$ der sauren Glycosaminoglycane des normalen Leberbindegewebes zu etwa gleichen Teilen aus Heparan-Sulfat und Dermatan-Sulfat bestehen. Die cirrhotische Leber zeigt einen starken Anstieg dieser Komponenten bei gleichzeitig hohem Gehalt an Hyaluronat. Die Ergebnisse werden im Hinblick auf die angewandte Methodik und die pathophysiologische Aussage diskutiert.

\section{The acidic glycosamine glycans in the connective tissue of normal and cirrbotic buman liver}

A method is reported for the isolation of acidic glycosamine glycans from human liver, and their separation into individual components. It was found that approximately equal quantities of heparan sulphate and dermatan sulphate together account for about $90 \%$ of the acidic glycosamine glycans of normal liver. These components are markedly increased in cirrhotic liver, and there is also a high concentration of hyaluronate. The methods used and the patho-physiological significance of the results are discussed.

Den sauren Glycosaminoglycanen kommt eine wesentliche Bedeutung für die Struktur und Funktion der Interzellularsubstanz der Bindegewebe zu. Ihre qualitative und quantitative Verteilung bestimmt in den verschiedenen Bindegeweben die für deren spezifische Funktionen typischen physikalisch-chemischen Eigenschaften.

1) Abkïrzungen: saure GAG (s. GAG) = saure Glycosaminoglycane; $\mathrm{CPC}=$ Cetylpyridiniumchlorid; $\mathrm{DS}=$ Dermatan-Sulfat; HPS = Heparan-Sulfat; $\mathrm{HP}=$ Heparin; $\mathrm{CH}-4-\mathrm{S}=$ Chondroitin4-Sulfat; $\mathrm{CH}-6-\mathrm{S}=$ Chondroitin-6-Sulfat; $\mathrm{CHS}=$ Chondroitinsulfate; Hyal $=$ Hyaluronat.
Die sauren Glycosaminoglycane als Komponenten der interzellulären Struktursubstanz werden damit zu Parametern, welche durch ihre Verteilungsmuster den jeweiligen Zustand der Gewebe zu charakterisieren vermögen. Physiologische und pathophysiologische Prozesse am Bindegewebe gehen mit qualitativen und quantitativen Veränderungen der Verteilungsmuster saurer Glycosaminoglycane einher (1-13).

Die Lebercirrhose ist geprägt durch eine unkontrollierte Proliferation des Bindegewebes, die u. a. mit dem Auftreten reifer kollagener Fasern an Stelle des feinen reticulären Fasergerüstes und einer Vermehrung. der 